\title{
MIDDLE PASSAGES OF THE SOUTHWEST INDIAN OCEAN: A CENTURY OF FORCED IMMIGRATION FROM AFRICA TO THE CAPE OF GOOD HOPE*
}

\section{Patrick Harries}

University of Basel

\begin{abstract}
Forced immigration from the Southwest Indian Ocean marked life at the Cape of Good Hope for over a century. Winds, currents, and shipping linked the two regions, as did a common international currency, and complementary seasons and crops. The Cape's role as a refreshment station for French, Portuguese, American, and Spanish slave ships proved particularly important in the development of a commerce linking East Africa, Madagascar, and the Mascarenes with the Americas. This slave trade resulted in the landing at the Cape of perhaps as many as 40,000 forced immigrants from tropical Africa and Madagascar. Brought to the Cape as slaves, or freed slaves subjected to strict periods of apprenticeship, these individuals were marked by the experience of a brutal transhipment that bears comparison with the trans-Atlantic Middle Passage. The history of the Middle Passage occupies a central place in the study of slavery in the Americas and plays a vital role in the way many people today situate themselves socially and politically. Yet, for various reasons, this emotive subject is absent from historical discussions of life at the Cape. This article brings it into the history of slavery in the region. By focusing on the long history of this forced immigration, the article also serves to underline the importance of the Cape to the political and economic life of the Southwest Indian Ocean.
\end{abstract}

\section{Key Words}

Southern Africa, African diaspora, slave trade, violence.

Weather patterns, ocean currents, and crop cycles created a southern, summer 'slave season' that brought the Cape into a network of exchange covering the Southwest Indian Ocean. Slave ships leaving Mozambique for the Americas took advantage of the northeast monsoon to sail south during the five to six months after September. The Mozambique Current aided this process, especially when, off the coast between Inhambane and Delagoa Bay, it fed into the Agulhas Current, a faster-flowing mass of water. Rounding the Cape, slave captains took advantage of the Benguela Current to cross the Atlantic in a northwesterly direction. They were assisted at this time of year by favourable southeast winds taking ships up the coastline or diagonally across the Atlantic to northeastern Brazil. From this point, captains could harness a clockwise 'wind carousel', that took them to the Caribbean, or turn south and, exploiting a similar, southern, anticlockwise movement of

\footnotetext{
* I want to thank Michael Aeby for his help with this article. Author's email: patrick.harries@unibas.ch
} 
wind, make their way to the markets of Rio de Janeiro and Rio de la Plata. ${ }^{\mathrm{I}}$ This southern 'wind wheel' then allowed them to turn back to the Cape from where they sailed north by tacking back and forth in the narrow band between the Agulhas Current and the coast or by sailing out to sea and up the eastern side of Madagascar. These seasonally favourable winds and currents eased the passage of slaves from the Mozambique Channel to the Cape and reduced the likelihood of their encountering the cold southern winter with its vicious gales, frightening storms, and occasional gigantic swells. Many slave traders in Mozambique added to the seasonal nature of this commerce by purchasing their human merchandise in the dry, southern winter when it was easier to move slaves to the coast and purchase food. ${ }^{2}$

Most slaves from Mozambique were latecomers to the Cape. During the seventeenth and eighteenth centuries, the Dutch East India Company (VOC) mounted over a dozen expeditions to Madagascar for slaves and, in the I720s, established a short-lived factory at Delagoa Bay for this purpose. ${ }^{3}$ While the Company brought to the Cape around 4,300 slaves, historians are less sure about the total number of bonded Africans landed and distributed, often illegally, during the VOC period. ${ }^{4}$ The limited success with which the colony looked to Madagascar and Mozambique for labour led the Company to rely for its slaves on the Indian subcontinent, Southeast Asia and the Indonesian archipelago. This produced a novel transoceanic trade in slaves as these forced immigrants arrived in Table Bay in small numbers to be sold by private individuals returning to the Netherlands or by owners seeking buyers for a range of commodities that included slaves. ${ }^{5}$ The nature of the slave trade changed radically in the I770s when East Africa became a renewed a site of operations for both the VOC at the Cape and planters on the French islands of île de France and Bourbon (Mauritius and Reunion). This led to a more systematized trade in slaves with the Cape as Dutch vessels sailed to Kilwa and Zanzibar in search of these human commodities and French merchants developed a trade in slaves with the Caribbean. ${ }^{6}$

I S. D. Behrendt, 'Ecology, seasonality, and the transatlantic slave trade', in B. Bailyn and P. L. Denault (eds.), Soundings in Atlantic History: Latent Structures and Intellectual Currents, I500-I830 (Cambridge, MA, 2009), 45-6.

2 J. Capela, 'A captura de escravos no sudoeste Africano para o tráfico a longa distância', Africana Studia, I4 (2OIO), 42.

3 K. Schoeman, Portrait of a Slave Society: The Cape of Good Hope, I7I7-I795 (Pretoria, 201 2), I 56-70 and 294-305; P. Westra and J. Armstrong (eds.), Slave Trade with Madagascar: The Journals of the Cape Slaver Leijdsman, I7I5 (Cape Town, 2006); D. Sleigh and P. Westra, The Taking of the Slaver Meermin, I766 (Cape Town, 20I3).

4 N. Worden, 'VOC Cape Town as an Indian Ocean port', in H. P. Ray and E. A. Alpers (eds.), Cross Currents and Community Networks: The History of the Indian Ocean World (New York, 2007), I45; P. Emmer, The Dutch Slave Trade: I500-I850, trans. C. Emery (Oxford, 2006), ix.

5 J. Armstrong and N. Worden, 'The slaves, I652-I 834', in R. Elphick and H. Giliomee, (eds.), The Shaping of South African Society (Cape Town, I989), I I 2; K. Ward, Networks of Empire: Forced Migration in the Dutch East India Company (Cambridge, 2009), I 46 and I 5 I.

6 R. Ross, 'The Dutch on the Swahili coast: I776-I778: two slaving journals, part I', International Journal of African Historical Studies, I9:2 (I986), 305-360; G. S. P. Freeman-Grenville, The French at Kilwa Island: An Episode in Eighteenth-Century East African History (Oxford, I965) 7, I3, and I9-21; A. Duminy, François Renier Duminy: French Mariner and South African Pioneer, I747-I8II (Pretoria, 2005), 56-8. 
This article traces the history of the movement of forced immigrants from tropical Africa to the Cape over a period of almost one hundred years, from I772-I864. As Nigel Worden has pointed out, the vibrant interest in the history of slavery at the Cape has not been matched by a similar concern with the slave trade. ${ }^{7}$ Propelled by the need to assess the origins of racism in the region, historians have shown little interest in the provenance of slaves, their long process of enslavement, or the nature of their transhipment. The absence of a clearly African community of slave descent has also contributed to this gap in the historical record. For many years, a soft version of the history of slavery contributed to an orientalist identity that separated 'Malays' from 'Other coloureds' at the Cape. Although historians over the last thirty years have successfully highlighted the harshness of slavery as an institution at the Cape, they have continued to focus their work on the history of the community drawn from the northern and eastern fringes of the Indian Ocean. ${ }^{8}$

This interest derives in part from the community's practice of Islam, a religion that set them apart in a colony ruled by Christians; but it also stems from the visible presence of their descendants who today constitute the 'Cape Moslem' or 'Malay' community. More recently, the sense of identity of this community has been strengthened by a resurgent 'Malayism' that rests on rediscovered diasporic links, a vibrant cultural heritage, and a history of slavery marked by discrimination and disadvantage. ${ }^{9}$ While historians have placed the political economy and culture of this 'Malay' community at the centre of their work on slavery, they have paid little attention to the early history of 'coloured identity', a subject focused overwhelmingly on the mixed-race nature of this community and its political struggles during the last hundred years. ${ }^{\text {Io }}$ This historiography has obscured the way in which slaves and forced immigrants from Africa arrived at the Cape with their own cultural practices, languages, and experience of enslavement; and it particularly overlooks the contribution of these Africans to the emergence of a distinctly 'coloured' community.

One of the aims of this article is to correct this perspective by foregrounding the 'Middle Passage' that brought slaves and other forced immigrants to the Cape from Africa, particularly from Mozambique and Madagascar. In some quarters of the United States, this

7 N. Worden, 'Ethnic diversity at the VOC Cape', in M. van de Geijn-Verhoeven et al., Domestic Interiors at the Cape and in Batavia, I602-I795 (The Hague, 2002), I3I; J. Hooper and D. Eltis, 'The Indian Ocean in transatlantic slavery', Slavery and Abolition, 34:3 (2013), 365.

8 A notable exception is N. Worden, 'Slavery and amnesia: towards a recovery of Malagasy heritage representations of Cape Slavery' Actes du Colloque International sur l'Esclavage, Antananarivo, 24-28 Septembre 1996 (Antananarivo, I997), 53-63.

9 P. Kaarsholm, 'Diaspora or transnational citizens? Indian Ocean networks and changing multiculturalisms in South Africa', Social Dynamics, 38:3 (2012), 457-8; S. Jappie, 'From the madrasah to the museum: the social life of the "kietaabs" of Cape Town', History in Africa, 38:I (20I I), 388-94. See also footnote 74; and N. Worden, 'The changing politics of slave heritage in the Western Cape, South Africa', The Journal of African History, 50:I (2009), 23-40; P. D. Gqola, What is Slavery to Me? Postcolonial/Slave Memory in Post-Apartheid South Africa (Johannesburg, 2010).

Io M. Adhikari, 'From narratives of miscegenation to post-modernist re-imaginging: towards a historiography of coloured identity in South Africa', in Adhikari (ed.), Burdened by Race: Coloured Identities in Southern Africa (Cape Town, 2009), I I-I 5; A. Eichmann, 'The heritage of slavery and nation building: a comparison of South Africa and Mauritius', in D. Hamilton, K. Hodgson, and J. Quirk (eds.), Slavery, Memory and Identity: National Representations and Global Legacies (London, 2012), 63-76. 
emotive topic has become almost a synecdoche for the slave experience. ${ }^{\text {II }}$ It is often seen as the 'incubator' of an African-American identity, a painful inheritance that is destructive but important to remember. ${ }^{\mathrm{I} 2}$ It is a major theme in historical fiction and cinema and, despite the remarkable achievements of new quantitative methodologies, it remains one of the most compelling aspects of slave studies. ${ }^{\mathrm{I} 3}$ In this article, the Middle Passage is understood as the bridging period between enslavement and arrival. Attention to this period serves both to fill an important gap in the historiography of the Cape and to underline the extreme violence that accompanied the forced immigration of a large part of the region's labour force. By examining the history of this forced immigration, the article also aims to explore the Cape's role in what Richard Allen has called the 'complex web of social, economic and political relations' in the Southwest Indian Ocean during the late eighteenth and early nineteenth centuries. ${ }^{\mathrm{I}} 4$

\section{THE SLAVE TRADE}

The Digue was one of the first French vessels to exploit the route around the Cape. On I7 April I772, it left Lorient for Port Louis where it spent six weeks at anchorage before sailing for the Querimba islands off the northern coast of Mozambique where, with the help of venal Portuguese officials, it spent three months collecting 333 slaves. Then, instead of making its way to île de France, the Digue set sail for Cap Français in St Domingue where planters were opening new land for coffee. However, as the Digue made its way south from Mozambique, large numbers of slaves started to die and the vessel's captain brought it into Table Bay where he secured the permission of the VOC to disembark the slaves and coax them into a renewed state of health. ${ }^{15}$

In the next few years, slavers from Nantes and Bordeaux joined those from Lorient in the search for slaves in East Africa. Through their trade with Spanish America, Bordeaux merchants accumulated the piastres or Spanish dollars that were the 'hard currency' of international trade. Traders in Mozambique eagerly sold slaves for this silver currency that linked them with the Cape, Gujerat, and other centres of trade. Pushed by the opportunities opened by this common means of exchange, French traders moved cautiously south of

I I M. Diedrich, H. L. Gates, Jr., and C. Pedersen (eds.), Black Imagination and the Middle Passage (New York, I999), 6.

I 2 S. Stuckey, Slave Culture: Nationalist Theory and the Foundations of Black America (New York, 20I3 [orig. pub. I987]), I. See also Toni Morrison's influential novel, Beloved: A Novel (New York, 2004 [orig. pub. I987]).

I3 M. Rediker, The Slave Ship: A Human History (New York, 2007), I2; J. Walvin, The Trader, the Owner, the Slave: Parallel Lives in the Age of Slavery (London, 2007), 73-4; S. Smallwood, Saltwater Slavery: A Middle Passage from Africa to American Diaspora (Cambridge, MA, 2007), IOI-52.

I4 R. B. Allen, 'The constant demand of the French: the Mascarene slave trade and the worlds of the Indian Ocean and Atlantic during the eighteenth and nineteenth centuries', The Journal of African History, 49:I (2008), 66.

I 5 T. Vernet, 'La première traite française à Zanzibar: le journal de bord du vaisseau l'Espérance, I774-I775', in C. Radimilahy, N. Rajaonarimanana (eds.), Civilisations des mondes insulaires: Madagascar, iles du canal de Mozabique, Mascareignes Polynésie, Guyanes (Paris, 20I I), 487-8; Voyages: The Trans-Atlantic Slave Trade Database (STDB), Voyage Identification number (VIN) 32982, (http://slavevoyages.org), accessed 22 April 2014 . 
Kilwa to buy slaves at the Portuguese island capital of Mozambique. About eight ships engaging in this trade stopped at the Cape before war with Britain in 1778 brought it to a halt. After the war, the Portuguese formally opened Mozambique to trade with the French and, following the termination of a string of conflicts with Makua chiefdoms, permitted the sale of guns and powder. The French crown encouraged this trade by subsidising the shipment of slaves to St Domingue. ${ }^{16}$ This caused the slave trade to be pursued with a new level of violence that brought a growing insecurity to Mozambique's hinterland just as it provided the port's administration with a solid source of revenue. It also caused the number of French slave ships anchoring in Table Bay to jump from three in $\mathrm{I} 784$ to eight the following year, and to grow precipitously in size and carrying capacity over the next few years. This brought sufficient slaves to the Cape for the VOC to end its costly East African slaving expeditions.

Although information about Dutch slave ships servicing the Cape has grown in recent years, little is known about their procurement practices or the conditions that prevailed in their dark holds. ${ }^{17}$ The habits of the French are more familiar due to the records of captain Joseph Brugevin, who in $\mathrm{I} 777$ brought a human cargo of 386 souls into Table Bay as he sailed from Kilwa and Mozambique to Cap Français. Eight years later, he returned from Bordeaux to the same area in the large, 625-ton Licorne and, on his return to Cap Français with 434 slaves, anchored in Table Bay for twelve days. ${ }^{18}$ Two years later, the Licorne stopped in Table Bay on its way to île de France with a cargo of wine and distilled alcohol, iron bars, cloth, trade guns, powder and ammunition, and an equal quantity in value of Spanish dollars. On his arrival at Port Louis, Brugevin had to sell a part of his cargo for the silver dollars needed to buy slaves as heightened competition had raised their price on the coast. Moreover, two supply brigs had spent six months on this coast during which they had collected little more than 200 slaves apiece. When Brugevin arrived at Ibo, one of the brigs supplied his vessel with 60 slaves; but he had little success at the island and sailed for Mozambique rather than delay his return to the unseasonable winter months. ${ }^{\text {I9 }}$

At the island capital, the Portuguese authorities obliged the Licorne to join a queue behind two Portuguese and three French slavers. It was only on 4 December I787, once the IIoo-ton Breton had left with 820 slaves, that the Licorne could start embarking its own forced emigrants. This gave rise to new problems as the health of the slaves already in its hold deteriorated further. The situation worsened for Brugevin as the large number of traders at Mozambique had created a sellers' market that obliged him to buy slaves in 'lots' that included old men and the sickly, as well as young children and women, alongside the valuable males of working age. The captain of the Licorne also complained that he had no control over what he called the 'racial' composition of the 'lots'. He considered those

I6 R. L. Stein, The French Slave Trade in the Eighteenth Century: An Old Regime Business (Madison, WI, I979), $40-2$.

I7 Exceptions are Schoeman, Portrait of a Slave Society, 163-5, I67-9; Sleigh and Westra, Taking of the Slaver Meermin, 26-9; and Duminy, François Renier Duminy, 68-9.

I 8 Freeman-Grenville, French at Kilwa, I9; E. Saugera, Bordeaux, port négrier: chronologie, économie, idéologie, XVIIe-XIXe siècles (Paris, I995), 355.

I9 E. Moufflet, 'Voyage d'un navire négrier (I787-I788)', Revue maritime et colonial, 7 (I892), 25 I-3 and 259. 
designated as 'Makuas' the best slaves as they were physically strong and possessed of good sea legs. Others, called 'Makondes' and 'Inhambanes' had a good work reputation but suffered from the melancholy that made them listless and tired, and that took them to an early grave. The least valuable were slaves from the interior who were easy to procure but as they had walked long distances to the coast, were often physically exhausted and mentally depressed on their arrival. As these 'Yaos' were consumed by the belief they were to be eaten, many refused the food and medicine that alone could strengthen them for the onerous long Middle Passage and, once on the coast, fell ill and died. ${ }^{20}$ Two hundred of the I,020 slaves purchased by the Breton had died this way and Brugevin was unwilling to invest in such unsound 'merchandise'. He was particularly concerned to keep the slaves in which he had invested both healthy and fit by providing them with large helpings of a mixture of rice, beans, and peas, alternated with smaller servings of boiled maize and biscuits of cassava or wheat. ${ }^{2 I}$

When Brugevin took the Licorne out of the deep water behind Mozambique Island in January $\mathrm{I} 788$, the main danger faced by the slaves on his ship came from a form of dysentery, considered incurable, that quickly took on epidemic proportions. In an attempt to ward off this illness and scurvy, crewmen served the slaves small quantities of water several times a day. Twice a week, and for the same purpose, they were fed a little red wine or a beverage composed of distilled alcohol, water, lemon juice, vinegar, and sugar. $^{22}$ Three days after leaving port, the Makuas rebelled. This was a constant danger for the crew of a slave ship and Brugevin's men were well-equipped to put down these shipboard disturbances. Armed with six swivel guns and several dozen handguns, blunderbusses, and sabres, the crew quickly overcame the rebellious slaves whose leader chose freedom by jumping overboard. Three members of the crew and twenty slaves were wounded in the insurrection and 80 participants were locked in neck irons and chains. By the time the Licorne approached Table Bay on Io February, six slaves had died of dysentery and forty were showing signs of scurvy. But conditions on the overcrowded Breton, which the Licorne found in the bay, were far worse. A slave rebellion and disease had ravaged the vessel and reduced its human cargo from 820 to 630 slaves. Brugevin took advantage of his anchorage off Cape Town to land sixty slaves considered unwell or incapacitated by wounds received in the uprising. He would eventually sell forty of these slaves to buyers at the Cape for 70 Spanish piastres each. With this income he loaded his ship with fresh bread and meat, 400 barrels of water, I0,000 pears and apples, I00,000 almonds, two barrels of dried raisins, and a great quantity of cabbages, carrots, and especially celery, which he considered particularly efficacious in fighting scurvy. ${ }^{23} \mathrm{He}$ had lost four slaves to exhaustion and disease during the stay at the Cape; but the sharp reduction in the size of his slave cargo had allowed him to take on the food and water needed to reduce the mortality experienced during the Atlantic crossing. ${ }^{24}$

\footnotetext{
20 Ibid. $256-8$.

2 I Ibid. $267-72$ and $275-7$.

22 Ibid. 270-I and 275-6.

23 G. Debien, 'Le voyage d'un navire négrier bordelais au Mozambique ( $\mathrm{I} 787-\mathrm{I} 788$ )', in F. Cadilhon (ed.), $\mathrm{La}$ France d'ancien régime: textes et documents, I484-I789 (Bordeaux, 2003), 232-3.

24 Five of the 395 slaves died during the Middle Passage. Moufflet, 'Voyage', 276.
} 
Brugevin's public report stressed the ways in which an efficient slave captain could reduce the depletion of his human cargo. Less public documents, such as the logbook of the slave ship Patriote, that left I 4 slaves at the Cape on its way from Mozambique to the Caribbean in $\mathbf{I} 790$, include laconic references to the rape suffered by female slaves at the hands of an all-male crew. ${ }^{25}$

By the end of the I 78 os, the Cape had become a vital anchorage for slave ships participating in the triangular trade between France, Mozambique, and St Domingue. At an average of close to 400 tons, the vessels plying this route were considerably larger than the slavers working the run between Mozambique and the Mascarenes and, carrying about 400 slaves each, were more heavily charged. Between I773 and I793, the average slaver took 35 days to get from Mozambique to Cape Town where it spent 25 days taking on food, water, and crew and, often, exercised slaves onshore. Ships took around I 30 days to get from Mozambique to St Domingue at this time. Shipping statistics indicate that these vessels lost some 3 I per cent of their human cargoes on this route, although these losses probably include an average of up to $6-7$ per cent left at the Cape. ${ }^{26}$ Both the length of the voyage and the slave mortality rate on vessels docking at the Cape were roughly the same as those experienced on slave ships sailing from Mozambique to the Mascarenes. ${ }^{27}$ As the trans-Atlantic slave trade reached its height between I789-90, and a paroxysm of greed seized the enterprise, almost fifty slave ships sailed from Southeast Africa to the Caribbean. High profits led traders to overcrowd smaller vessels that took longer to reach their destination. They carried well over I6, I0o slaves and, although about half the vessels stopped at the Cape, they 'lost' some 42 per cent of their human cargo during the long Middle Passage. ${ }^{28}$ The commerce with St Domingue peaked at this time but came to a quick halt in August I79I after the slave uprising on the island. Attempts to divert slave cargoes from the Cape to Havana proved unsuccessful and, as war with Britain loomed again early in $\mathrm{I} 793$, the last slave ship sold its 337 forced immigrants in Cape Town rather than risk capture during the Atlantic crossing to Cuba. ${ }^{29}$

The outbreak of war led the British to seize the Cape in I795 and, two years later, establish a vice-admiralty court that legalized the capture and condemnation of French and allied vessels. Taken as 'prizes of war', these vessels frequently contained slave cargoes. So while the war prevented the French from shipping slaves to the Cape for sale, it resulted in the landing and sale of 'prize slaves' at the new British colony. It also resulted in a change of ownership as the French sold their ships to a small group of merchants operating from

25 F. Hubert et al., Bordeaux au XVIIIe siècle: Le commerce atlantique et l'esclavage (Bordeaux, 20I0), 98; Saugera, Bordeaux, port négrier, 358.

26 National Archive, the Netherlands, Scheeps Rolle, I.04.02, shipping lists for I779-89, inventory numbers 4324-36. My thanks to Annie Goodner for compiling this list. STDB, (http://slavevoyages.org/tast/ database/search.faces?yearFrom=I770\&yearTo=I793 \&mjbyptimp=60820), accessed 22 March 20 I 4.

27 E. Alpers, 'Becoming "Mozambique": diaspora and identity in Mauritius', in E. Alpers and V. Teelock (eds.), History, Memory and Identity (Port Louis, Mauritius, 200I), I 35.

28 J. Capela, O tráfico de escravos nos portos de Moçambique: 1733-1904 (Lisbon, 2002), 3II; Saugera, Bordeaux, port négrier, IIO; STDB, (http://slavevoyages.org/tast/database/search.faces?yearFrom= I 789\&yearTo=I 790\&mjbyptimp=60800), accessed 26 March 20 I 4.

29 STDB, Helvétie VIN 33082 and S. Pedro VIN 4I320, (http://slavevoyages.org/tast/database/search.faces? yearFrom $=\mathrm{I} 770$ \&yearTo=I 793 \&mjbyptimp=60820), accessed 22 April 2014. 
Mozambique Island. As Portuguese citizens, these merchants could travel safely around the Cape, sell slaves at the port, or use it as a refreshment station. They created a network of trust and credit centred on the family but also worked closely with each other and with members of the colonial administration at Mozambique. They particularly benefitted from the formal opening of Brazil to slaves from Mozambique; and, with the beginning of a decade of peace with France in 1797, they reinvigorated their ties with the Mascarenes and added a profitable new slave route from Mozambique to Rio de la Plata, the southern gateway to Spanish America. ${ }^{30}$

The slavers at Mozambique established agents at the Cape to look after their interests, raised loans and securities, and sought buyers for their human merchandise at the port. Slave ships returning from Brazil to Mozambique sometimes stopped at the Cape to sell cargoes of sugar, coffee, and rice, and purchase wheat flour, wine, and other goods for ile de France. $^{3 \mathrm{I}}$ Like the French before them, the Portuguese traders sold weak and infirm slaves at the Cape and, on occasion, received permission from the governor to sell their entire human cargoes at the British port. Some local traders co-sponsored voyages with Portuguese colleagues or mounted their own expeditions to Mozambique, buying slaves openly or clandestinely. During the final years of the eighteenth century, most slave ships going to Brazil and Montevideo stopped in Table Bay for water and supplies. ${ }^{32}$ When South Carolina reopened the slave trade in I804, these vessels were joined by others taking slaves to Charleston. ${ }^{33}$ This pattern changed little as the Dutch and British fought to hold the Cape. Slave vessels brought over 7,200 forced immigrants to the Cape between I797 and I 808 when slaves from Mozambique, particularly those of working age, came to dominate the colony's population of bonded labourers. ${ }^{34}$ As first clerk in the customs house at the Cape, Samuel Hudson observed the arrival of these 'wretches, torn from their country, friends and relatives, [who] subsist for two months cooped up in so small a space that humanity shudders upon reflecting at the horrors of such a confinement'. 'I have frequently', he continued, 'heard of small vessels losing on a voyage from Mozambique 130 to 200 slaves merely from bad treatment, want of room, want of water and provisions and everything that could make such a state bearable.' 35

30 R. Ross, 'The last years of the slave trade to the Cape Colony', Slavery and Abolition, 9:3 (I988), 209-I9; L. Antunes, 'O comércio com o Brasil e a comunidade mercantil em Moçambique (séc. XVIII)', Dimensões: Revista da Historia de Ufes, I9 (2007), 207-20; P. Machado, 'A forgotten corner of the Indian Ocean: Gujarati merchants, Portuguese India and the Mozambique slave trade, c.I730-1830', Slavery and Abolition, 24:2 (2003), 17-32.

3 I See Cape Town Gazette (CTG), I:27, I4 February I80I; CTG, I:29, 8 May I802. For the earlier period, see Allen, 'Constant demand', 6I; and Freeman-Grenville, French at Kilwa, 93.

32 Capela, Tráfico de escravos, 79; J.-P. Tardieu, La traite des Noirs entre l'océan Indien et Montevideo (Uruguay): Fin du XVIIIe siècle et début du XIXe (Paris, 2010), Io, 20, 55, 67, and 87; A. Borucki, 'The slave trade to the Río de la Plata, I777-I8I2: trans-imperial networks and Atlantic warfare', Colonial Latin American Review, 20: I (201 I), 95.

33 Kaapsche Courant, 5 Nov. I803, 28 April I804, I6 Feb. and I Nov. I805; M. H. Styles, Captain Hogan: Sailor, Merchant, Diplomat on Six Continents (Fairfax Station VA, 2003), I67-8.

34 M. C. Reidy, 'The admission of slaves and "prize slaves” into the Cape Colony, I797-I 8I 8' (unpublished MA thesis, University of Cape Town, I997), 5-6; Ross, 'Last years', 2 I6.

35 R. Shell (ed.), “'Slaves”: an essay by Samuel Eusebius Hudson', Kronos, 9 (I984), 4I. 
In March I 807, fifteen months after the British ended a renewed Dutch occupation of the Cape, parliament in London passed the Act of Abolition. This terminated the legal importation of slaves to the Cape on I March I 808 but made no impression on the burgeoning trade in slaves from Mozambique to Brazil. Although the new act prohibited naval officers from selling captured slaves, it offered them a considerable fixed sum for each 'prize' slave, amounting to $£_{4} 0$ for a man, $£_{3} \circ$ for a woman, and $£_{\mathrm{I} O}$ for a child. In this way, slaves continued to be valuable 'prizes', although in a new form, and British warships continued to hunt down French slave ships off the Mascarenes and bring in other enemy vessels. The British authorities at the Cape also used various legal ploys to liberate slaves at the Cape where, like those brought in as prizes, they were served with fourteen-year apprenticeships. ${ }^{36}$

The legal grounds on which the Royal Navy captured slave vessels became less certain when peace returned to the seas at the end of the Napoleonic Wars. No longer protected by the rights of belligerents, the British entered into a series of international treaties that brought the navy to focus its antislavery activities on Freetown and to severely reduce its role at the Cape. But during the decade of action against the slave trade, starting in I 808, around 2,600 slaves had been liberated at the Cape and a good deal of information had emerged about both their provenance in Mozambique and their passage south.

\section{PROVENANCE AND EXPORT OF SLAVES}

Under Portuguese law, all exports from Mozambique, including slaves, had to pass through the customs house of the island capital. This law lengthened the slaves' long Middle Passage as it required them to be funnelled through Mozambique from all points along the coast. It also brought long caravans of slaves to the mainland opposite Mozambique Island where they were sold at taverns and fairs, branded or rebranded, and taken across the bay to storehouses and barracoons. ${ }^{37}$ Epidariste Colin, an intellectual figure at île de France, described how traders in Mozambique sent agents far into the interior to acquire slaves in exchange for piastres, cotton cloths, beads, and sugar. Coffles of up to 500 slaves travelled to the coast largely at night, carrying heavy consignments of ivory, avoiding Makua villages, and scavenging for roots and plants along the way. Half would often die during the journey to the coast. ${ }^{38}$ Colin described most of the slaves brought from deep in the interior as Yaos (Monjavas) who, as in Brugevin's day, had the unenviable reputation of dying in large numbers during the long Middle Passage. Traders now also acquired Maravis deep in the interior and they, too, were deemed of little value due to the poor condition in which they arrived on the coast. Makuas remained the most prized of all the slaves, largely because they were bought, traded, or captured at little distance from Mozambique and were fit and strong when sold to the slave ships. But although

36 P. Harries, 'Negotiating abolition: Cape Town and the trans-Atlantic slave trade', Slavery and Abolition, 34:4 (2013), 579-597.

37 Capela, Tráfico de escravos, 232; E. Alpers, Ivory and Slaves in East Central Africa (London, I975), 201-2 and 229.

38 E. Colin, 'Notice sur Mozambique', in Malte-Brun (ed.), Annales des voyages, de la géographie et de l'histoire 9 (I 809$)$, 3 I 2-I 5 . 
the Makuas had the physical resilience needed to survive the long Middle Passage, they were also reputed to be dissident, rebellious, and violent. Colin viewed Makonde slaves as second only to Makuas. ${ }^{39}$

The route to Mozambique became increasingly unsafe after the Makua chiefdoms acquired guns and powder, and it moved in a starkly new direction when the French invaded Portugal and, from his exile in Rio de Janeiro, the prince regent opened the ports of Mozambique to Brazilian traders. With their skills, capital, and social networks, these slavers soon started to displace the merchants at Mozambique who had dominated the slave trade for close on two decades. Brazilians particularly implanted themselves at Quelimane when in I8I 2 the town acquired its own customs house. Behind Quelimane, the Zambezi had long acted as an artery of commerce penetrating deep into the continent. Along the banks of the great river, Portuguese prazeiros had come to develop vast estates with the help of an array of unfree labourers. Many people fell into slavery on the prazos when kidnapped or captured in war, when they pawned themselves to escape debt or starvation, or when they experienced the social death caused by expulsion from the home community. ${ }^{\circ}$ Some slaves came to constitute an upwardly mobile caste of soldiers who, adopting the title Chikunda, oversaw production on the prazos. The Chikundas also seized and traded two categories of slaves: those marked for export and those distributed as field hands to a class of servile, tenant farmers, or colonos. With the help of their slaves, these serf-like farmers produced goods for the market and provided the prazeiros and their Chikunda slaves with taxes and tribute. ${ }^{4 \mathrm{I}}$

The profits of the slave trade and the opening of Quelimane to direct trade with Brazil brought a new disequilibrium to life on the prazos. As traders at Mozambique invested the profits of their profession in land, the estates changed hands. These new prazeiros lacked the feudal responsibilities of previous generations and, deeply immersed in the slave trade, saw the agriculturalists on their lands as the merchandise of their profession. As the profits of the slave trade to Brazil grew and Quelimane became a major point of exit for slaves, the Chikunda transgressed established practice by exporting the slaves working the prazos and then even the colono tenants. ${ }^{42}$ This caused the production of goods on the estates to collapse and soon slaves seemed the only marketable article. Between I8I4-20, over I 5,000 slaves left Quelimane for Brazil. In the I820s, this total would increase to around 7,600 every year. ${ }^{43}$

The growth of the slave trade at Quelimane did little to diminish the role of Mozambique's island capital as an exporter of slaves. In I8I9, Father Bartolomeu dos Mártires undertook a systematic study of the human cost of the slave trade from

\footnotetext{
39 Colin, 'Notice sur Mozambique', 320.

40 Capela, Tráfico de escravos I7-I 8; M. Newitt, A History of Mozambique (London, I995), 252.

$4 \mathrm{I}$ A. Isaacman and B. Isaacman, Slavery and Beyond: The Making of Men and Chikunda Ethnic Identities in the Unstable World of South-Central Africa, I750-I920 (Portsmouth, NH, 2004), 39-82; Capela, Tráfico de escravos, 247-8; T. I. Mathews, 'Portuguese, Chikunda, and peoples of the Gwembe Valley: the impact of the "lower Zambezi complex" on southern Zambia', The Journal of African History, 22:I (I98I), 23-4I.

42 L. Vail and L. White, Capitalism and Colonialism in Mozambique: A Study of Quelimane District (London, I980), 26-8.

43 D. Eltis, Economic Growth and the Ending of the Transatlantic Slave Trade (New York, I987), $250-\mathrm{I}$.
} 
the port. He considered most of the slaves brought to Mozambique to be criminals who had broken the laws of their land and become social outcastes. Others had been kidnapped or were prisoners of war. The questions Mártires put to traders showed that, of the 9,855 slaves arriving on the beaches opposite Mozambique Island in I8I9, I 2 per cent died before they could be sold. In the holding pens on the island, another I 2 per cent succumbed to exhaustion and disease. On their journey to Brazil in that year, the slaves were packed into the holds of 16 vessels where just over 25 per cent lost their lives, contributing to an overall mortality rate of close to 50 per cent. ${ }^{44}$

The conditions under which the Dutch shipped slaves to the Cape found little place in their reports, apart from comments raised in response to official protests about financial losses incurred by an excessive mortality. But in an age of slave reform, Epidariste Colin's description of life in the hold of a slave ship sailing from Mozambique to île de France produced a new and moving picture. Published in I 809 , during the siege of the island by the Royal Navy, it could have applied to any one of the captured slave vessels taken to the Cape. 'After having bought them', Colin wrote of the slaves at Mozambique,

one usually obliges them to take an emetic to clear their stomachs before sending them on board where the strongest amongst them are put in chains. Regular and abundant food suddenly replaces the roots that they have eaten during a long voyage, something that produces an abrupt change in mood that causes many to perish. They leave; sea-sickness, the little air that circulates in the place where they spend the night, the stinking odours emanating from the hold; the buckets in which they leave their excrement and that they only change every four days; the worries that they must have, believing as they do that the whites intend to eat them; all of this adds to the horror of their situation. ${ }^{45}$

Colin held that placing the slaves in irons merely made them more restless and encouraged them to rise against the crew. The more submissive Yao and Maravi slaves needed to be separated from the Makuas and Makondes who regarded them as their inferiors and goaded them into acts of resistance. Women particularly fanned the resentment behind the uprisings on slave ships and needed to be securely separated from men. Colin also thought the sick should be held in the ships' boats as, although this left them open to the elements, it restricted the spread of disease. Like Brugevin, he saw dysentery as the major killer on a slave ship. Removing the tubs of excrement from the hold and allowing slaves to defecate from the deck would improve their living quarters and reduce the death rate. He recommended a more varied diet and, although costly in terms of space, sufficient casks of water to allow the slaves to drink their fill during the voyage. Colin felt the hold should be better ventilated and that slaves should be washed and exercised twice a day. Supplying them with drums and stringed instruments would get them to dance and sing in a manner that would keep up their strength and reduce depression. ${ }^{46}$

44 B. dos Mártires, 'Memoria corographica da provincia de Moçambique', in V. Rau, 'Aspectos étnico-culturais da Ilha de Moçambique em I 822', Studia, I I (I963), I48-5I; Capela, 'A captura de escravos', 45-6; Alpers, Ivory and Slaves, $2 \mathrm{I}$ I-I 2 and 229-30.

45 Colin, 'Notice sur Mozambique', 324.

46 Ibid. $325-28$. 
The shipboard experience of slaves taken to the Cape became increasingly visible when the British started to enforce the treaty system aimed at suppressing the slave trade. With the rise of abolitionist feeling, and often with a great deal of prize money at stake, British officials compiled moving descriptions of the conditions endured by slaves between their sale on the Mozambican coast and their landing at the Cape. A prize crew boarding the Portuguese ship São Joaquim in February I8I 5 found it to be carrying 340 slaves, ivory, tortoise shell, and other goods. After 22 days at sea some 42 slaves had died and, once at anchor in Simon's Bay, another I3 passed away. But the I 6 per cent death rate on the vessel was less extraordinary than the conditions under which slaves lived in the hold of the vessel. ${ }^{47}$ The African Institution reported that Lt James Eicke had found 'all of them sickly and weak, nearly one hundred of them afflicted with the flux',

the slaves were all stowed together perfectly naked; and nothing but rough, unplaned [sic] planks to crouch down upon, in a hold situated over their water and provisions, the place being little more than two feet in height, and the space allowed for each slave being so small that it was impossible for them to avoid touching and pressing upon those immediately surrounding. The greater part of them were fastened, some three together, by one leg, each in heavy iron shackles; a very large proportion of them having the flux that they were compelled to perform their natural vacuations under these dreadful circumstances, without being able to move; and to remain amidst their own excrement, which could not be cleared away, until said Slaves were all disembarked. ... That more than one hundred of them were at the time of their landing just like skeletons covered with skin and moving slow machinery, hardly maintaining the appearance of animated human beings. ${ }^{8}$

Landing the slaves brought little relief to another 43 of their company who died before they were in fit condition to be apprenticed. The Cape government received 25 male and two female slaves from the São Joaquim while those remaining were assigned to individual masters for 14 years. Despite the horrible conditions on the ship, the São Joaquim had broken no law and its owners later successfully claimed compensation of almost $£_{\text {I } 5,750}$ for wrongful seizure. ${ }^{49}$

Another glimpse into life in the hold of a slave ship at the Cape occurred in February I 8 I 8 with the arrival of the Flor de Babia. ${ }^{\circ}$ The merchant ship Atlas had seized the Portuguese vessel at sea after its chief mate had accidentally discovered slaves packed into the vessel's long boat. On opening the hatches in the morning, the dead body of a slave was handed up and thrown overboard and soon after, two female slaves, naked, and skeletal, were observed crawling about the deck. ${ }^{5 \mathrm{I}}$ Another witness recounted that the brig was 'so overcrowded with slaves that there was not really room enough for them to lie straight'. The vessel had been at sea for 22 days during which time 2 I per cent of its human cargo had died. The 389 slaves left alive were in such poor shape on their arrival in Table Bay that $5 \mathrm{I}$ had to be disembarked for medical attention,

47 The National Archives, London (TNA), Foreign Office (FO) 308/I, 23, 62, 70, 93-5, 3 I6, 369; Cape Almanac (Cape Town), I8 6 .

48 African Institution Report (I8I8), 27; T. F. Buxton, The African Slave Trade (London, I839), I IO.

49 See footnote 47; and the Vice-Admiralty records, TNA High Court of the Admiralty 42/506/I I64.

50 The Cape Almanac (I8I8); STDB, VIN 49786, (http://slavevoyages.org), accessed 22 April 20 I4.

5 I Cape Archives (CA) Colonial Office (CO) 4362, deposition by R. Chrystie, I9 Mar. I8I8. 
an action that led to much soul-searching on the part of the British authorities when they had to re-embark the slaves and see them depart for Brazil. ${ }^{22}$ The 160-ton Paquet Real arrived in Table Bay from Mozambique on 23 April I8I8. Crowded with 237 slaves, it had taken 64 days to work its way slowly down the coast of Southeast Africa. Some 52 slaves had died during this tortuous voyage and another I I expired as the vessel lay at anchor in Table Bay. An early winter storm then drove the vessel onshore. ${ }^{53}$ Rescuers pulled I40 slaves from the sea but the corpses of 25 washed ashore and seven more died later of their exertions. The 133 survivors were in a 'deplorable state', wrote the colonial secretary, 'totally naked ... debilitated and diseased'. All were hospitalised for some time before being apprenticed to individual masters for I4 years. ${ }^{54}$

During the decade after the implementation of the Act of Abolition in I 808, most of the slaves freed at the Cape came from various parts of Southeast Africa via the ports of Mozambique and Quelimane. This region of Africa also supplied a sizeable part of the 724 'Madagascan' captives freed at the Cape by the Royal Navy. ${ }^{55}$ But the movement of liberated slaves to the Cape halted as the treaty system took the fight against the slave trade north of the equator to focus on Freetown. It was only in the late I 830 , after a confluence of political changes, that the Cape re-emerged as a site for the freeing of slaves.

\section{MANY MIDDLE PASSAGES}

Many of the treaties entered into by Britain in an attempt to outlaw the slave trade included a mutual right to search vessels for slaves. A major, persistent problem for the Royal Navy was that warships could only seize vessels when carrying slaves. Pressured by the Foreign Office, the Spanish eventually agreed in 1835 to allow their ships to be seized when outfitted with the accoutrements of the slave trade such as hatches with open grates, decks, iron manacles and bolts, large boilers, and excessive amounts of food, matting, and money. This 'equipment clause' led to the seizure of large numbers of Spanish ships but it also caused others to shelter under the Portuguese flag. The treaty system allowed Portuguese vessels to run slaves from Angola and Mozambique to Brazil, and the number of slaves exported grew rapidly as Portugal extended this protection to other nations, particularly Spain. This eventually led the British to pass a law in I839 unilaterally allowing their warships to stop and search Portuguese vessels. ${ }^{56}$

52 Captain José dos Santos Ferreira to Lord Charles Somerset, 26 Feb. I 8 I 8, in G. M. Theal (ed.), Records of the Cape Colony (RCC) XI, 46I-2; TNA FO 308/2, 233-34, Commissioner A. Marsden to G. Canning, I7 Mar. I823.

53 TNA FO 308/I/42-43, Commissary judges, Mixed Commission, London, 9 Dec. I8I9; CA Government House $(\mathrm{GH}) \mathrm{I} / 23$, C. Robinson and R. Gifford, 'Case of the Paquet Real', in Colonial Agent to Somerset, 28 Nov. I 8I 8; Somerset to Bathurst 2I May I8I 8 in Theal (ed.), RCC XII, 7.

54 Colonial Secretary to Collector of Customs I9 May I8 8 in Theal (ed.), RCC XII, 5.

55 P. Larson, Ocean of Letters: Language and Creolization in an Indian Ocean Diaspora (New York, 2009), 240.

56 P. Harries, 'The hobgoblins of the middle passage: the Cape of Good Hope and the trans-Atlantic slave trade', in U. Schmieder, K. Fülberg-Stolberg, and M. Zeuske (eds.), The End of Slavery in Africa and the Americas: A Comparative Approach (Berlin, 20II), 27-50. 
A few weeks after the passage of 'Palmerston's Law', the naval squadron based at Simonstown started to capture and bring in large vessels carrying hundreds of slaves. The final emancipation of slaves in I 838 had brought a labour shortage to the Cape. But it had also freed the labour market from the shackles of slavery, a turn of events reinforced when the governor issued a proclamation reducing to one year the periods of apprenticeship of what were now called 'captured Negros'. ${ }^{57}$ In November I 839, the Ana Feliz became a target of this new labour regime when, off Quelimane with 56 slaves on board, half of them children, it encountered HMS Modeste. Most of the slaves were in the vessel's hold, some hidden in lifeboats, others secreted in divisions built into the bulkhead of the ship. After sending the captured prize to Cape Town for trial before the vice-admiralty court, the Modeste continued to patrol the waters off Quelimane and, two weeks later, seized the Escorpião with a cargo of 7I6 slaves packed onto a deck I07 feet long, 25 feet 6 inches wide, and 3 feet 3 inches high. Fourteen slaves died of what seemed like dysentery and scurvy during the eighteen-day voyage to Simonstown where another I4 died after disembarkation. But the illness was soon discovered to be smallpox and, when the vice-admiralty court finally condemned the Escorpião on the 24 February I 840, only 606 slaves remained alive. Nine more died before masters came forward to apprentice the survivors. ${ }^{5}$ In that month, the Modeste seized the Amizade Constante off the Zambezi River mouth. There were 620 slaves on board the prize when, on the way south, the smallpox ravaging the coastal population broke out in the vessel's hold. This led to the death of 74 slaves before the vessel anchored in Simon's Bay. But sickness continued to reduce their number after disembarkation and, on the I April, only 477 remained alive. ${ }^{59}$

Naval warships based at the Cape captured around forty slave vessels between November I 839 and August I 842 when the Portuguese brought this undeclared state of war to an end by accepting the equipment clause and the establishment of a mixed commission at Cape Town. But by this time the range of British warships had extended to include the South Atlantic. In August I84I, a cargo of I 50 slaves captured on the Anna by the Royal Navy off Benguela had to endure a double crossing of the ocean when, hauled before the Anglo-Brazilian mixed commission in Rio de Janeiro, their vessel was redirected to Table Bay at the request of the Cape's governor. ${ }^{60}$ For several months in I 842, vessels took I, 360 slaves from the bulking centre at St Helena to Cape Town where they supplied the post-emancipation labour needs of the colonists. This scheme came to an end as the labour requirements of sugar planters in the West Indies proved greater than those of grain and wine farmers at the Cape; but it did swell the cosmopolitan nature of

57 Proclamation of I3 Dec. I 839 in Cape of Good Hope Government Gazette, 3 Jan. I 840.

58 TNA FO 84/437, 'Schedule of male and female negroes on board the Escorpião', Vice-Admiralty Court, Cape of Good Hope, 24 Feb. I 840; TNA FO 84/385, H. Eyres, commander of HMS Modeste, deposition of 20 Apr. I 84I; TNA Admiralty (ADM) 7/6I7, W. Robson to Lords Commissioners of Her Majesty's Treasury in Treasury to Captain Eyres, Io Jan. I 845 .

59 TNA FO 84/437, Deposition before Court of Vice-Admiralty, Merrington, I Apr. I840; CA CO 49I3, Bell to Field, I3 Mar. I840.

60 South African Commercial Advertiser (SACA), I and 4 Dec. I84I, I40 and I42. 
the African population in Cape Town and surrounding districts by bringing to it a wave of forced immigrants whose original homes were in West and West-Central Africa. ${ }^{6 I}$

On 30 August I 843, HMS Arrow captured an unnamed brig loaded with 337 slaves off Lobito in southern Angola. The vessel's human cargo was in dire straits, partly because the slaves were largely children and partly because the captain, fearing arrest under the equipment clause, had not installed a slave deck and, instead, had stowed his merchandise directly on barrels of water in the hold. The captain of the Arrow sent his prize to St Helena but the poor condition of the slaves led 49 to die before the vessel anchored off the island. Another 2 I died before the governor finally refused to accept them and redirected the brig to Cape Town. Eighteen more slaves died on the way to Table Bay and a further 22 on their disembarkation at the port on 23 October. Their trials were not yet over, for by the time they were finally liberated on 28 November, another I 8 slaves had died. This meant that 38 per cent of the original slave cargo had died while in the charge of the Royal Navy. ${ }^{62}$ HMS Thunderbolt, a six-gun paddle steamer, also operated in the waters off southern Angola at the end of I 843 where it captured three vessels leaving Benguela. These carried a total of $\mathrm{I}, 200$ slaves, reputedly worth $£ 80-\mathrm{I} 20,000$ in Brazil. On their arrival in Table Bay, a Cape Town newspaper wrote with shock of these vessels where 'the space between decks where the living cargo was stowed away, was so small that young children, boys and girls from eight to twelve years of age could not creep on their hands and knees: they were pushed in, or, lying flat on their faces, crawled in like worms! ${ }^{63}$

Certainly the most infamous of the slave ships bringing forced immigrants to the Cape at this time was the Progresso. The vessel left Angoche on the Mozambican coast in April I 843 with 447 slaves on board. The slaves were packed into the ship-of barely I 40 -tons - along a deck 46 feet long, 25 feet wide, and 3 feet 6 inches high. When a boarding party from HMS Cleopatra took hold of the vessel they found it in a high state of confusion as the slaves had been released from below and, starved of water and food, had consumed anything from seawater and raw alcohol to live chickens. Although fifty slaves were transferred to the Cleopatra, the Progresso remained heavily overloaded and, with its canvas in tatters, made slow progress. On the first night, when the weather turned bad and the sails had to be brought down, the slaves were forced back into the narrow confines below deck. This led to pandemonium in the hold as they reoccupied the stinking hole in which they had experienced so much fear and misery, and were again deprived of their access to food and water. The next morning, sailors retrieved fifty bodies from the hold of the vessel. Over the following day, the Progresso inched its way down the coast and the slaves started to die. They were in such poor condition, after a long march to the coast and an extended detention at Angoche, that the captain of the slave ship had refused to take fifty on board. Those who were embarked suffered from craw-craw and dysentery. They were almost naked and, as the ship progressed southward, they suffered increasingly from the autumnal cold - as well as from the storms that tossed them around

\footnotetext{
6I C. C. Saunders, 'Liberated Africans in Cape Colony in the first half of the nineteenth century', International Journal of African Historical Studies, I 8:2 (I985), 232.

62 TNA FO 84/458, HMCs to Earl Aberdeen, 20 Dec. I 843.

63 SACA, 24 and 27 Jan. I844, 4I and 50.
} 
in the hold. The vessel took fifty days to get to Simonstown, by which time I77 slaves had died. The survivors were in such a state of exhaustion that, after landing, another 63 succumbed to their long ordeal, a mortality rate of 54 per cent. ${ }^{64}$ The furore caused by this scandalous death rate on a vessel manned by a prize crew of the Royal Navy heightened criticisms of the antislavery squadron and led the Admiralty to search for alternative ways to bring an end to the slave trade.

\section{CONCLUSION}

The enormous profitability of the slave trade to Brazil drove the forced emigration from Mozambique. In the I830s and I840s, slaves bought in Portuguese Africa could sell for many times their cost price in Brazil. ${ }^{65}$ On the Zambezi, this source of easy money led the prazeiros to export not only the slaves and colonos who worked their estates but even the Chikunda overseers who protected them. Frequent droughts and the arrival of Nguni warlords from the south added to the insecurity in the region while, in the north, traders pressed ever further into the continent in search of slaves. ${ }^{66}$ Creole slaves, who spoke some Portuguese, exercised recognisable skills and perhaps worshipped a single god, now fetched far higher prices as ladinos or creoles than the brutos or bossales found deep in the interior. Taken to Mozambique in long coffles or in the holds of small dhows, the slaves were assembled on the island under armed guard in feitorias with large courtyards, high walls, and easy access to the sea. Although traders on the island now divided their human merchandise into distinct classes, they treated them with the same brutal disinterest when, faced by the prospect of insurrection in the courtyards, they held them naked, chained them by the neck, and sometimes manacled their feet. ${ }^{67}$

The growing violence of this world beset by the slave trade could be read in the wave of Portuguese-speaking 'Antonies' and 'Pedros' appearing in the register of liberated slaves in Cape Town. ${ }^{68}$ But another change could also be read in the register for, as the slave trade shifted northwards in the late 1840 , the number of slaves freed at the Cape declined sharply. After I838, the Admiralty paid a bounty on the tonnage of ships captured under the equipment clause and naval captains had less financial reason to hunt down vessels laden with slaves. The captains of slave ships also developed a new strategy when they ran their vessels aground in a way that allowed their crews to escape but consigned their human cargoes to a watery grave. This forced the British to house slaves rescued from sinking vessels on the decks of their warships. The practice of transferring slaves to naval vessels grew as British captains chose to measure the tonnage of empty

\footnotetext{
64 F. L. Barnard, A Three Years' Cruise in the Mozambique Channel (New York, I97I [orig. pub. I848]), 40, 43-4, and 222; P. G. Hill, Fifty Days on Board a Slave-Vessel in the Mozambique Channel, in April and May, I 843 (London, I 844).

65 R. W. Beachey, The Slave Trade of Eastern Africa (London, I976), I9.

66 E. de Froberville, 'Notes sur les Va-Niungue et les Mabsiti: peuples de l'Afrique orientale', Bulletin de la Société de Géographie, 3:Io (I 849), 65-8I; Newitt, History of Mozambique, 253-5 and 265-6.

67 Anon., Nouvelles annales des voyages, 4 (I 840 ), 250-I.

68 Register of prize Negroes, 24 Oct. I843-30 Jan. I847 in CA, Collector of Customs 382.
} 
prizes and destroy those considered ill-fitted to make the journey to the Cape. Increasingly, these vessels came to consist of small Arab dhows operating out of hidden coves and river mouths. This turn of events shifted the visible suffering of the slaves to the lifeboats and decks of the Royal Navy's warships but, at the same time, encouraged captains to disembark their captive passengers at Mauritius. ${ }^{69}$ The end of the Brazilian slave trade in $\mathrm{I} 85 \mathrm{I}$ sealed the decline in the number of forced immigrants liberated at the Cape and, a decade later, most slaves were freed at the Seychelles. Reduced to little more than a trickle, the shipment of forced immigrants to the Cape came to an end in I864 when warships brought I7 stateless dhows and I74 slaves before the vice-admiralty court in Cape Town. ${ }^{70}$

Over the next decade, the British turned a deaf ear to requests from the Cape for slaves to be liberated and apprenticed in the colony. But with the curtailment of slavery at Zanzibar in 1873 , they agreed to ship freed slaves to Durban from the island. Over the next few years, about 550 slaves arrived in this manner in the British colony of Natal where, held by five-year contracts, they established a largely Makua-speaking community. ${ }^{7 \mathrm{I}}$ These 'Zanzibaris' (see Kaarsholm in this special feature) formed part of a diaspora of Mozambican origin in many parts of the Southwest Indian Ocean: Caffres in Reunion, Creoles in Mauritius, as well as Makoa and Masombika in Madagascar. ${ }^{72}$

In the south, the descendants of African slaves at the Cape came to constitute a 'Mozambiquer' or 'Mozbieker' community, easily distinguished by language, complexion, body marks, cultural practices, and experience from the Xhosa-speakers who, in the I 870s, arrived in considerable numbers from the Eastern Cape. Many threw off the weight of slavery by melting into the mixed-race coloured population. In I9I I, the first census of the Union of South Africa classified those who retained a Mozbieker identity as a 'mixed race' group, alongside 'Malays' and others. But as race became a primary factor in population taxonomy, Mozbiekers were reclassified as a 'tribe' of the 'Bantu race'. This subjected them to a raft of discriminatory legislation and most quickly abandoned their ethnonym and adopted a broad, 'coloured' identity. ${ }^{73}$ With a clear reason to turn their backs on their African origin, Mozbiekers disappeared into this amorphous creole community, and soon forgot the distinct experience of their ancestors. This left the primary

69 Nouvelles annales des voyages, 4 (I840), 248-9; House of Commons Parliamentary Papers (HCPP) I846, (723) Correspondence of British Commissioners on the Slave Trade, 676-7; Journal of Paymaster Frederic Lucas, HMS Mutine, 6 May-I6 June I845, (http://www.pbenyon.plus.com/RN/Lucas_Journal.html), accessed ${ }_{5}$ Sept. 2013. See also M. Carter, V. Govinden, and S. Peerthum, The Last Slaves: Liberated Africans in I9th Century Mauritius (Port Louis, 2003).

70 HCPP г 865 (3503), Correspondence with British Commissioners at the Cape of Good Hope, I864, 70.

7 I E. Alpers, 'The other middle passage: the African slave trade in the Indian Ocean', in E. Christopher, C. Pybus, and M. Rediker (eds.), Many Middle Passages: Forced Migration and the Making of the Modern World (Berkeley, CA, 2007), 24-6; Kaarsholm, 'Diaspora or transnational citizens?', 459-62.

72 D. Nativel and F. Rajaonah (eds.), Madagascar et l'Afrique: entre identité insulaire et appartenances historiques (Paris, 2007), 24; E. Alpers, 'Mozambique and "Mozambiques": slave trade and diaspora on a global scale', in B. Zimba, E. Alpers, and A. Isaacman (eds.), Slave Routes and Oral Tradition in Southeastern Africa (Maputo, 2005), 39-6I.

73 P. Harries, 'Making Mozbiekers: history, memory and the African diaspora at the Cape', in Zimba Alpers, and Isaacman (eds.), Slave Routes and Oral Tradition, I20-I. 
heritage of slavery at the Cape to the 'Malays', a community united by a distinctive Muslim identity and an orientalist view of the peculiar institution. ${ }^{74}$

By considering the experience of forced immigrants from Africa and Madagascar during their Middle Passage to the Cape, this article has examined one aspect of the extreme violence associated with slavery. In the process it has drawn attention to an unsettling experience that, because it requires confrontation with a painful past, might seem unwise to remember. Yet for the descendants of slaves in many parts of the Southwest Indian Ocean, the Middle Passage haunts the construction of identity and selfhood. Recognized or not, it is an essential part of both a slave heritage and a political future.

74 S. Jeppie, 'Reclassifications: Coloured, Malay, Muslim', in Z. Erasmus (ed.), Coloured by History, Shaped by Place: New Perspectives on Coloured Identities in Cape Town (Cape Town, 200I), 80-96; G. Baderoon, 'The African Oceans - tracing the sea as memory of slavery in South African literature and culture', Research in African Literatures, 40:4 (2009), 89-107. 